\title{
BAP and IBA pulsing for in vitro multiplication of banana cultivars through shoot-tip culture
}

\author{
M. H. Ferdous ${ }^{a}$, A. A. Masum Billah ${ }^{b}$, H. Mehrajc, T. Taufique ${ }^{d}$ and A. F. M. Jamal Uddin ${ }^{d, *}$ \\ Dept. of Genetics and Plant Breeding, Sher-e-Bangla Agricultural University, Dhaka-1207, Bangladesh \\ ${ }^{b}$ Dept. of Agriculture Extension, Ministry of Agriculture, Iswardi, Pabna, Bangladesh \\ 'The United Graduate School of Agricultural Sciences, Ehime University, 3-5-7 Tarami, Matsumaya, Ehime \\ 790-8556, Japan \\ dDept. of Horticulture, Sher-e-Bangla Agricultural University, Dhaka-1207, Bangladesh
}

\begin{abstract}
ASTRACT
The study was undertaken with a view to establish a protocol for in vitro plant regeneration from shoot tip explants of banana. Different concentrations of BAP $(0.0,1.0,2.0,3.0,4.0,5.0,6.0$ and 7.0 $\mathrm{mg} / \mathrm{l})$ and IBA $(0.0,1.0,2.0,3.0,4.0$ and $5.0 \mathrm{mg} / \mathrm{l})$ was used in MS medium to assess the influence on in vitro shoot regeneration and subsequent root formation of Amritasagar and Sabri banana cultivars. Maximum single shoot formation (50.0\% and 30.0\%), number of single shoot (3.50 and $2.00 \mathrm{in})$, longest shoot (2.64 cm and $2.16 \mathrm{~cm})$ were found from $0.5 \mathrm{mg} / \mathrm{l} \mathrm{BAP}$ while maximum number of roots (3.83 and 2.50) and longest root (3.60 cm and $3.10 \mathrm{~cm}$ ) was found from $0.3 \mathrm{mg} / \mathrm{l}$ IBA in Amritasagar and Sabri respectively. The survival of the plantlets of both cultivars was more than $82 \%$ under ex vitro condition. $0.5 \mathrm{mg} / \mathrm{l}$ BAP and $0.3 \mathrm{mg} / \mathrm{l} \mathrm{IBA}$ can be used with MS media for shoot and root formation of Amritasagar and Sabri banana cultivars through shoot tip culture.
\end{abstract}

Keywords: Banana, growth regulators, in vitro shoot-tip culture and plantlets regeneration

Please cite this article as: Ferdous, M. H., Masum Billah, A. A., Mehraj, H., Taufique, T. \& Jamal Uddin, A. F. M. (2015). BAP and IBA pulsing for in vitro multiplication of banana cultivars through shoot-tip culture. Journal of Bioscience and Agriculture Research 03(02): 87-95.

This article is distributed under terms of a Creative Common Attribution 4.0 International License

\section{Introduction}

Banana (Musa spp.) belongs to Musaceae family. It is clonally propagated and attacked by wide range of diseases and pests (Cronauer and Krikorian, 1983) which affect yield. Disease free plant material should be produced to minimize this problem which can be possible by meristem culture because pathogen concentration gradually decreases in shoot tips and considered to be absent or less in meristem. Tissue culture plants have been reported to produce 39\% higher yield than plants from sword suckers (Pradeep et al., 1992) likely performed better than in banana (Faisal et al., 1998). Shoot apex, nodal segments and root segments were successfully used for callus induction and regeneration (Jatoi et al., 2001) and cytokinin helps in shoot multiplication (Cronauer and Krikorian, 1984a). 
Growth regulators namely auxin, cytokinin, gibberellin and abscisic acid like kinetin, indole-3-acetic acid, benzylaminopurine etc were used for the in vitro regeneration of various plants (Ali et al., 2014 and 2015; Momena et al., 2014). Cytokinins such as benzylaminopurine (BAP) are known to reduce apical meristem dominance and induce both axillary and adventitious shoots formation from meristematic explants in banana (Madhulatha et al., 2004). Effectiveness of BAP over other cytokinins in inducing multiplication of shoot tip cultures has been reported in different banana cultivars (Buah et al., 2010; Farahani et al., 2008; Rahman et al., 2006; Resmi and Nair, 2007). The most established banana shoot-tip culture system was achieved by using BAP as a supplement to basal media (Murashige and Skoog, 1962) and its effect in stimulating growth of axillary and adventitious buds also foliar development of shoot tip cultures (Buah et al., 2010). Considering the constraints behind disease free planting materials and potential of tissue culture through shoot-tip and or meristem, the study was undertaken to assess the suitable concentration of BAP for in vitro shoot proliferation and root induction of two banana cultivars, namely, cv. Amritasagar and cv. Sabri, for plantlets regeneration.

\section{Materials and Methods}

Laboratory and period of the experiment: The study was carried out at the laboratory of Proshika Tissue Culture Centre Trust, Manikgonj, Bangladesh from the April, 2008 to November, 2008.

Genetic materials: Banana cv. Amritasagar (Musa sapientum, Genotype AAA) and Sabri (Musa sapientum, Genotype AAA) were used in the experiment.

Concentrations of BAP and IBA: Different concentrations of BAP $(0.0,1.0,2.0,3.0,4.0,5.0,6.0$ and $7.0 \mathrm{mg} / \mathrm{l})$ on shoot multiplication and IBA $(0.0,1.0,2.0,3.0,4.0$, and $5.0 \mathrm{mg} / \mathrm{l})$ for rooting of two cultivars of banana was studied.

Culture media for in vitro: Both for shoot regeneration and rooting of multiplied shoots MS medium (Murashige and Skoog, 1962) was used with different vitamins and hormonal supplementation. Hormones were added separately to different media according to the requirements. For the preparation of media, stock solutions were prepared at the beginning and stored at $4 \pm 1^{\circ} \mathrm{C}$ temperature. The respective media were prepared from the stock solutions. The culture tubes containing media, beakers, pipettes, measuring cylinder, metal instruments were autoclaved at 15 psi pressure at $121^{\circ} \mathrm{C}$ for 20 minutes. The medium was then cooled at room temperature before use. Laminar Airflow Cabinet was usually sterilized by switching on the UV light of the cabinet for 30 minutes and wiping the working surface with $70 \%$ ethyl alcohol for 30 minutes before starting the transfer work.

Sample collection and preparation for in vitro culture: Meristem was collected from developing suckers from field for both cultivars. The suckers were washed thoroughly under running tap water. The roots and outer tissues of the suckers were removed with the help of a sharp knife. A number of outer leaves were removed until the shoot measured about $1.5-2.0 \mathrm{~cm}$ in length and $1.0 \mathrm{~cm}$ width at the base. The prepared explants were taken into a conical flask and were washed with distilled water containing 1\% savlon and 3-4 drops of Tween-80 for 20 minutes to remove dusty substance and followed by successive 3 times washing with distilled water to make the materials free from savlon and Tween-80. Subsequently the materials were transferred to running Laminar Airflow Cabinet.

Surface sterilization: The surface sterilization of explants was carried out in $0.1 \% \mathrm{HgCl}_{2}$ for different periods $(10,12,14,16$ minutes). Then the materials were washed 3-5 times with distilled water to remove all traces of $\mathrm{HgCl}_{2}$.

Inoculation of plant materials: The shoot tip explants of about $0.5 \mathrm{~cm}$ long with $3-4$ leaf primordial were prepared. The individual shoot tip was directly inoculated to each culture vessel and covered with plastic cap. After that the caps were sealed with parafilm. 
Transfer to growth chamber: The culture vessels were transferred to growth room and were allowed to grow in controlled environment $\left(25 \pm 2^{\circ} \mathrm{C}\right.$ temperature, 16-hour light period and 2000 lux light intensity) for the growth and development of the cultures.

Sub-culturing: For sub-culturing, the entire samples of in vitro shoots were cut into small pieces so that each piece would contain about one shoot. Leaf and blackish or browned basal tissues were removed to expose the meristem. Each piece was inoculated into a similar fresh medium. It was practiced at the interval of every one month. In vitro proliferated micro shoots were separated and each of the micro shoots was placed on culture medium.

\section{Results and Discussion}

\section{Effect of different strength of $\mathrm{HgCl}_{2}$}

After 10 days of sterilization and inoculation, it was observed that when the explants were treated with $0.1 \% \mathrm{HgCl}_{2}$ for 14 minutes, $100 \%$ shoot tip explants of Amritasagar and Sabri were found free from any contamination (Table 01). On the other hand, the percentage of contaminated explants increased at 20 days after sterilization and inoculation because there were endogenous bacteria in the meristem of explants that expressed later. When $\mathrm{HgCl}_{2}$ was used for short durations (10 and 12 minutes), the treatments failed to kill the microorganisms attached to the surface of field grown explants. Among the periods of treatment, the highest percent of explants survived at 14 minutes (Table 01).

Treatments for more than 14 minutes duration survival percentage was decreased and tissue became damage. So, concentrations of disinfectants and soaking time are adjusted according to the resistance of the explants to sterilants. Microbes like bacteria, fungi and virus are the most common contaminants observed in cultures. To overcome this sterilizing agents with different concentrations are generally used like $0.25 \%$ sodium hypochlorite (Vessey and Revera, 1981) chlorine saturated water for 15-20 minutes (Dore et al., 1983), 0.05\% sodium hypochlorite (Cronauer and Krikarion, 1984a).

Table 01. Standardization of $\mathrm{HgCl}_{2}$ treatment period for surface sterilization of shoot tips of Amritasagar and Sabri

\begin{tabular}{cccccc}
\hline Cultivars & $\begin{array}{c}\text { Treatment period of } \\
0.1 \% \mathrm{HgCl}_{2} \text { (min.) }\end{array}$ & $\begin{array}{c}\text { No. of explants } \\
\text { cultured }\end{array}$ & \multicolumn{2}{c}{$\begin{array}{c}\text { \% of explants } \\
\text { contaminated after }\end{array}$} & $\begin{array}{c}\text { \% of explants } \\
\text { survived after }\end{array}$ \\
\cline { 4 - 6 } & 10 & 10 & 60 & 80 & 20 days \\
\hline Amritasagar & 10 & 10 & 50 & 70 & 20 days \\
Sabri & 12 & 10 & 30 & 40 & 60 \\
Amritasagar & 12 & 10 & 30 & 40 & 60 \\
Sabri & 14 & 10 & - & 10 & 90 \\
Amritasagar & 14 & 10 & - & 10 & 90 \\
Sabri & 16 & 10 & - & 20 & 80 \\
Amritasagar & 16 & 10 & - & 30 & 70 \\
Sabri & 16 &
\end{tabular}

Explants were surface sterilized with $0.1 \% \mathrm{HgCl}_{2}$. Contamination free culture with higher surviving ability was achieved by treating the explants with $0.1 \% \mathrm{HgCl}_{2}$ for 14 minutes. It indicated that the duration of soaking of explants and the concentrations of the disinfectants were important factors to sterilize the explants.

\section{Different concentrations of BAP on shoot multiplication}

Relative colour changes of explants: After inoculation to the culture media, the shoot tips showed creamy white appearance at first sight and gradually became brown to light green, green and finally dark green on MS medium supplemented with different concentrations of BAP (Plate 01 and 02) and colour changing observed regularly. 
The explants became dark green at $3.0 \mathrm{mg} / \mathrm{l}$ and $5.0 \mathrm{mg} / \mathrm{l}$ at $10 \mathrm{DAI}$ (days after inoculation) but at 1.0 $\mathrm{mg} / \mathrm{l}, 2.0 \mathrm{mg} / \mathrm{l}, 4.0 \mathrm{mg} / \mathrm{l}, 6.0 \mathrm{mg} / \mathrm{l}$ and $7.0 \mathrm{mg} / \mathrm{l}$ BAP the inoculated explants became green and light green in control while all explants treated with BAP turned dark green in colour except in control i.e., $0.0 \mathrm{mg} / \mathrm{l} \mathrm{BAP}$ at $20 \mathrm{DAI}$ in Amritasagar cultivar (Table 02). In Sabri cultivar, after 10 days, the explant colour was green for $3.0 \mathrm{mg} / \mathrm{l}, 6.0 \mathrm{mg} / \mathrm{l}$ and $7.0 \mathrm{mg} / \mathrm{l}$ BAP concentrations while light green for 1.0 $\mathrm{mg} / \mathrm{l}, 2.0 \mathrm{mg} / \mathrm{l}, 4.0 \mathrm{mg} / \mathrm{l}$ and $5.0 \mathrm{mg} / \mathrm{l} \mathrm{BAP}$ concentrations but brown in control (Table 02). On the other hand, after 20 days, all the explants turned dark green for all concentrations of BAP except in control and $1.0 \mathrm{mg} / \mathrm{l} \mathrm{BAP} \mathrm{(Table} \mathrm{02).} \mathrm{In} \mathrm{control,} \mathrm{the} \mathrm{colour} \mathrm{was} \mathrm{light} \mathrm{green} \mathrm{in} \mathrm{Sabri} \mathrm{and} \mathrm{green} \mathrm{in}$ Amritasagar after 20 DAI (Rabbani et al., 1996). Therefore, it was clear that BAP was essential for early greening of the banana cultivars. Colour changes of inoculated explants showed clear variation in the same treatment for different varieties. It was probably due to genotype variation. Presence of cytokinin in the medium was essential for greening of banana shoot tip explants (Ranjan et al., 2001).

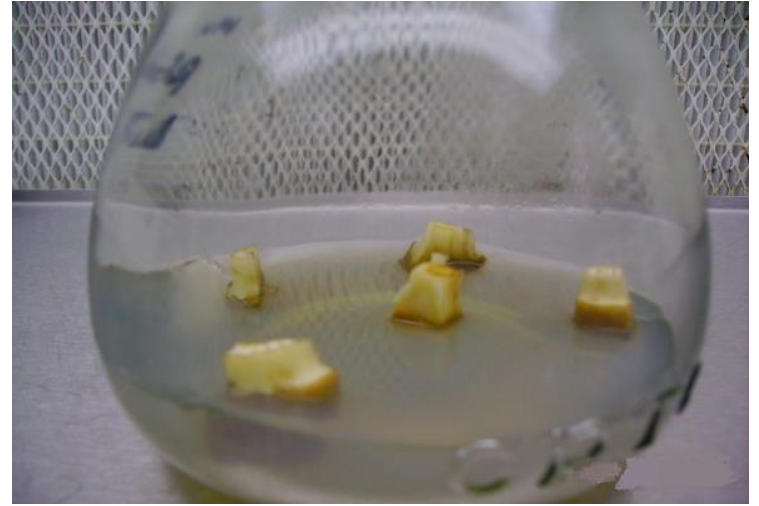

Plate 01. A just inoculated shoot tip isolated from a sucker showed creamy white colour

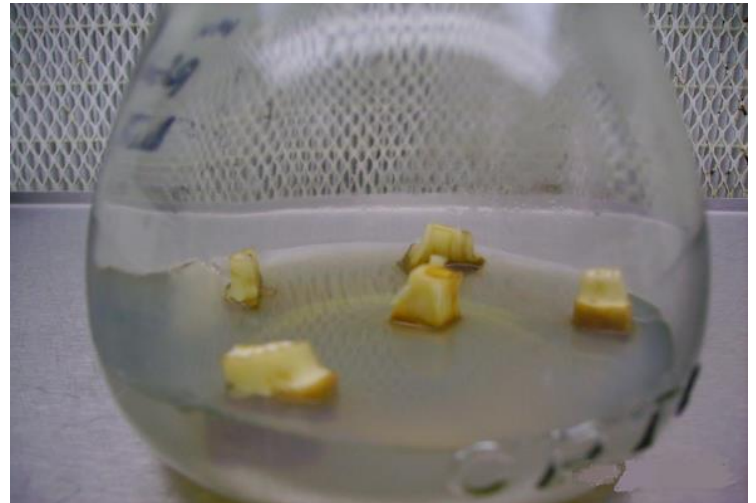

Plate 02. Inoculated shoot tip became dark green in colour

Table 02. Effect of different concentrations of BAP on relative colour changes of banana $\mathrm{cv}$. Amritasagar and Sabri

\begin{tabular}{|c|c|c|c|c|}
\hline \multirow{3}{*}{$\begin{array}{c}\text { Treatments } \\
\text { Conc. of BAP (mg/l) }\end{array}$} & \multicolumn{4}{|c|}{ Banana cultivars } \\
\hline & \multicolumn{2}{|c|}{ Amritasagar } & \multicolumn{2}{|c|}{ Sabri } \\
\hline & 10 days & 20 days & 10 days & 20 days \\
\hline 0.0 & + & ++ & $\mathrm{B}$ & + \\
\hline 1.0 & ++ & +++ & + & ++ \\
\hline 2.0 & ++ & +++ & + & +++ \\
\hline 3.0 & +++ & +++ & ++ & +++ \\
\hline 4.0 & ++ & +++ & + & +++ \\
\hline 5.0 & +++ & +++ & + & +++ \\
\hline 6.0 & ++ & +++ & ++ & +++ \\
\hline 7.0 & ++ & +++ & ++ & +++ \\
\hline
\end{tabular}

B indicates Brown; + indicates Light Green, ++ indicates Green, +++ indicates Dark Green

Tuber like structure developed from meristem explants: The cultured meristem formed hard meristematic tuber like structure in regeneration media containing different concentrations of BAP. In Amritasagar and Sabri, maximum rate of forming tuber like structure were $60.0 \%$ and $40.0 \%$ respectively on MS medium with $5.0 \mathrm{mg} / \mathrm{l}$ BAP while minimum $20.0 \%$ and $10.0 \%$ in Amritasagar and Sabri respectively on MS medium without any hormone. Therefore, Amritasagar showed better performance in formation of tuber like structure over Sabri. Some tuber like structures formed from the base of the shoot during shoot multiplication (Habib, 1994). These structures of banana are very good for germplasm preservation and can be utilized for further multiplication and subsequently mass proliferation of ideal plantlets for commercial exploitation. 
Survivability: Maximum survivability was found in MS medium containing $5.0 \mathrm{mg} / \mathrm{l} \mathrm{BAP}(90.0 \%$ in Amritasagar and $80.0 \%$ in Sabri) and minimum in $0.0 \mathrm{mg} / \mathrm{l} \mathrm{BAP} \mathrm{(50.0 \%} \mathrm{in} \mathrm{Amritasagar} \mathrm{and} \mathrm{40.0 \%} \mathrm{in}$ Sabri) (Table 03). However Amritasagar showed better survivability over Sabri for all the treatments.

Regeneration of single shoot from meristem explants: Maximum single shoot from meristem was regenerated at $5.0 \mathrm{mg} / \mathrm{l} \mathrm{BAP} \mathrm{(50.0 \% )} \mathrm{whereas} \mathrm{minimum} \mathrm{from} 1.0 \mathrm{mg} / \mathrm{l} \mathrm{BAP} \mathrm{(20.0 \% )} \mathrm{in} \mathrm{Amritasagar}$ cultivar and maximum single shoot from meristem was produced at $5.0 \mathrm{mg} / \mathrm{l}$ BAP (30.0\%) whereas minimum at $1.0 \mathrm{mg} / \mathrm{l} \mathrm{BAP}(10.0 \%)$ in Sabri while single shoot was not regenerated in control (Table 03). It was observed that single shoot regeneration was lower in Sabri compared to Amritasagar and the average time required for single shoot regeneration was higher than Amritasagar (Table 03). BAP was required for the single shoot regeneration (Rabbani et al., 1996). The results indicated that the percentage of single shoot regeneration increased with the increase of BAP concentration up to 5.0 $\mathrm{mg} / \mathrm{l}$ and there after declined.

Days to single shoot development: Early single shoot was developed at $5.0 \mathrm{mg} / \mathrm{l} \mathrm{BAP} \mathrm{(12.0} \mathrm{days} \mathrm{by}$ Amritasagar and 14.0 days by Sabri) (Table 03). Time requirements for single shoot formation to be 10-15 days (Rehana, 1999) which was close to the present investigation.

\section{Table 03. Response of cv. Amritasagar and Sabri banana cultivars to different concentrations of BAP at 20 DAI from meristem in vitro}

\begin{tabular}{|c|c|c|c|c|c|c|c|c|}
\hline \multirow{3}{*}{ 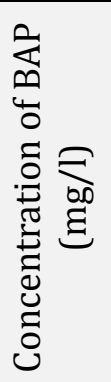 } & \multicolumn{8}{|c|}{ Banana cultivars } \\
\hline & \multicolumn{4}{|c|}{ Amritasagar } & \multicolumn{4}{|c|}{ Sabri } \\
\hline & 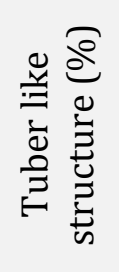 & 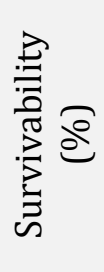 & 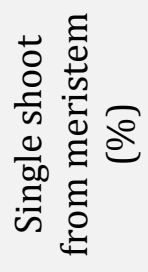 & 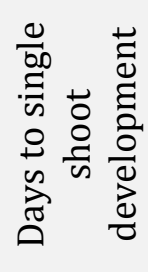 & 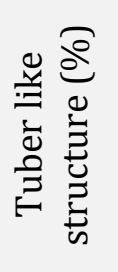 & 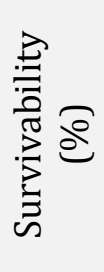 & 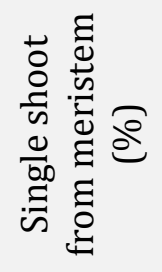 & 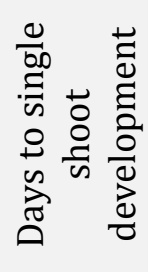 \\
\hline 0.0 & 20.0 & 50.0 & - & - & 10.0 & 40.0 & - & - \\
\hline 1.0 & 30.0 & 70.0 & 20.0 & 17.0 & 30.0 & 50.0 & 10.0 & 20.0 \\
\hline 2.0 & 30.0 & 70.0 & 30.0 & 16.0 & 20.0 & 70.0 & 20.0 & 19.0 \\
\hline 3.0 & 40.0 & 80.0 & 40.0 & 15.0 & 30.0 & 70.0 & 20.0 & 17.0 \\
\hline 4.0 & 50.0 & 80.0 & 40.0 & 13.0 & 30.0 & 60.0 & 30.0 & 15.0 \\
\hline 5.0 & 60.0 & 90.0 & 50.0 & 12.0 & 40.0 & 80.0 & 30.0 & 14.0 \\
\hline 6.0 & 40.0 & 70.0 & 40.0 & 14.0 & 30.0 & 70.0 & 20.0 & 15.0 \\
\hline 7.0 & 30.0 & 60.0 & 30.0 & 15.0 & 20.0 & 50.0 & 20.0 & 15.0 \\
\hline
\end{tabular}

*Ten explants were inoculated/treatment

Number of shoots per explant: Maximum number of shoots proliferation per explant was found from $5.0 \mathrm{mg} / \mathrm{l}$ BAP (3.50 in Amritasagar and 2.00 in Sabri) at 30 DAI while both cultivars showed no response in $0.00 \mathrm{mg} / \mathrm{l} \mathrm{BAP}$ (Table 04). The multiple shoot regeneration due the application of $0.5 \mathrm{mg} / \mathrm{l}$ BAP treatments was presented in Plate 03 and 04 . The number of shoots increased with the increase of BAP concentration up to $5.0 \mathrm{mg} / \mathrm{l}$ and then decreased. $5.0 \mathrm{mg} / \mathrm{l}$ BAP showed the best performance and Amritasagar was better variety than Sabri. BAP at the rate of $5.0 \mathrm{mg} / \mathrm{l}$ produced the highest number of shoots in Amritasagar and Mehersagar (Rabbani et al., 1996). Banana (AAA) meristem tip generated maximum number of shoots on MS medium supplemented with $6 \mathrm{mg} / \mathrm{l} \mathrm{BAP}$ in the cultivar Amritasagar (Khanam et al., 1996; Domingues et al., 1995).

Shoot length: Shoot length also influenced by cultivars and different concentrations of BAP Data at 10, 20 and 30 DAI (Table 05). Longest shoot was found from $5.0 \mathrm{mg} / \mathrm{l} \mathrm{BAP}$ in both cultivars but the cultivar Amritasagar produced longer shoot $(2.64 \mathrm{~cm})$ compared to Sabri (2.16) at 30 DAI (Table 04) whereas shoots were not produced when the BAP were not used on the culture media. $5.0 \mathrm{mg} / \mathrm{l}$ BAP was provided the longest shoot (Rabbani et al., 1996; Khanam et al., 1996.) and Amritasagar showed better performance over Sabri in case of shoot length. Amritasagar showed better performance over Sabri in case of shoot length. 


\section{Table 04. Combined effect of cultivars and concentrations of BAP on number of shoots per explants and length of shoots}

\begin{tabular}{|c|c|c|c|c|c|c|c|}
\hline \multirow[t]{2}{*}{ Cultivars } & \multirow{2}{*}{$\begin{array}{c}\text { Conc. of } \\
\text { BAP } \\
(\mathrm{mg} / \mathrm{l})\end{array}$} & \multicolumn{3}{|c|}{$\begin{array}{l}\text { Number of shoots per explant at } \\
\text { different days after inoculation }\end{array}$} & \multicolumn{3}{|c|}{$\begin{array}{l}\text { Shoot length }(\mathrm{cm}) \text { at different days } \\
\text { after inoculation }\end{array}$} \\
\hline & & 10 days & 20 days & 30 days & 10 days & 20 days & 30 days \\
\hline \multirow{8}{*}{ 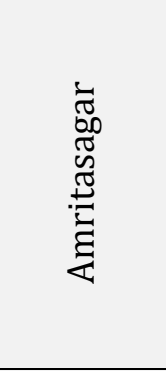 } & 0.0 & 0.00 & 0.00 & 0.00 & 0.00 & 0.00 & 0.00 \\
\hline & 1.0 & 0.00 & 0.33 & 0.60 & 0.00 & 0.09 & 0.86 \\
\hline & 2.0 & 0.30 & 0.62 & 1.65 & 0.04 & 0.71 & 1.82 \\
\hline & 3.0 & 0.65 & 1.33 & 2.25 & 0.08 & 1.30 & 2.35 \\
\hline & 4.0 & 0.67 & 1.33 & 2.33 & 0.09 & 1.35 & 2.47 \\
\hline & 5.0 & 1.00 & 1.72 & 3.50 & 0.14 & 1.36 & 2.64 \\
\hline & 6.0 & 0.36 & 0.71 & 1.33 & 0.06 & 0.91 & 2.13 \\
\hline & 7.0 & 0.30 & 0.37 & 1.00 & 0.00 & 0.42 & 0.96 \\
\hline \multirow{8}{*}{$\frac{\bar{\Xi}}{\pi}$} & 0.0 & 0.00 & 0.00 & 0.00 & 0.00 & 0.00 & 0.00 \\
\hline & 1.0 & 0.00 & 0.00 & 0.33 & 0.00 & 0.00 & 0.33 \\
\hline & 2.0 & 0.00 & 0.32 & 1.30 & 0.00 & 0.30 & 1.15 \\
\hline & 3.0 & 0.00 & 0.65 & 1.32 & 0.00 & 0.70 & 1.60 \\
\hline & 4.0 & 0.00 & 0.68 & 1.35 & 0.00 & 0.73 & 1.82 \\
\hline & 5.0 & 0.00 & 1.00 & 2.00 & 0.00 & 0.90 & 2.16 \\
\hline & 6.0 & 0.00 & 0.69 & 1.00 & 0.00 & 0.26 & 1.54 \\
\hline & 7.0 & 0.00 & 0.67 & 0.68 & 0.00 & 0.23 & 0.95 \\
\hline
\end{tabular}

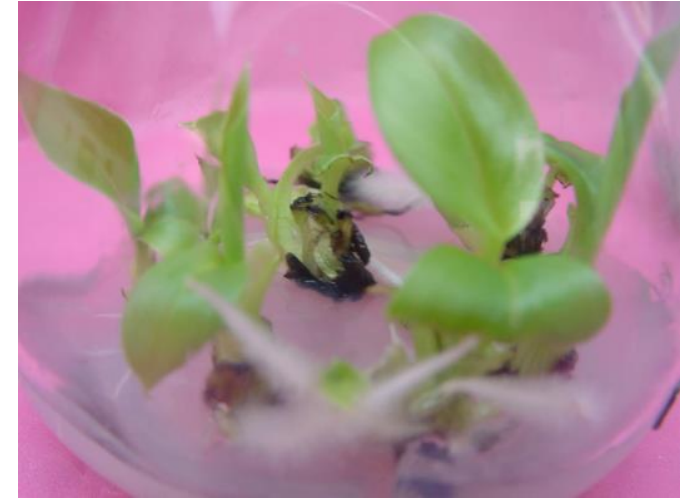

Plate 03. Multiple shoot of Amritasagar produced on MS medium containing $5.0 \mathrm{mg} / \mathrm{l}$ BAP at 30 days after inoculation

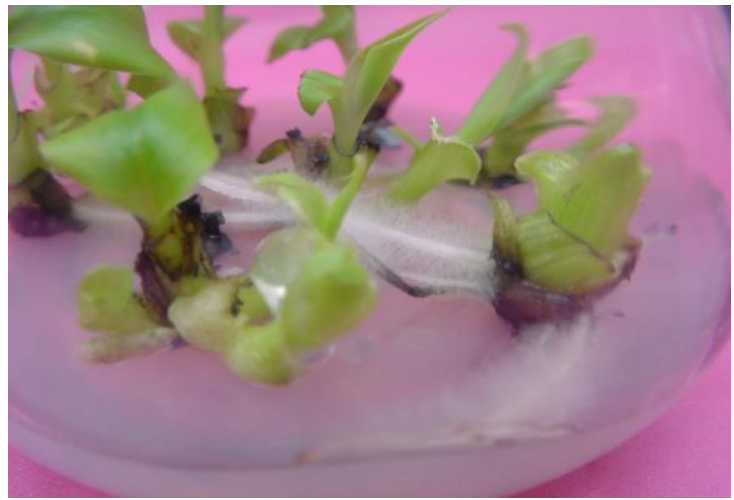

Plate 04. Multiple shoot of Sabri produced on MS medium containing $5.0 \mathrm{mg} / \mathrm{l}$ BAP at 30 days after inoculation

Number of leaves per plantlet: Among the concentrations of BAP, $5.0 \mathrm{mg} / \mathrm{l}$ showed maximum number of leaves in both the cultivars at different DAI. The cultivar Amritasagar produced 4.11 leaves per plantlet in $5.0 \mathrm{mg} / \mathrm{l} \mathrm{BAP}$ at $30 \mathrm{DAI}$ while Sabri produced 2.67 leaves per plantlet at the same level of BAP and DAI (Table 05). Leaf number per plantlet increased with the increase of BAP concentration up to $5.0 \mathrm{mg} / \mathrm{l}$ and then decreased in both the cultivars. Rabbani et al. (1996) also found that $5.0 \mathrm{mg} / \mathrm{l}$ BAP concentration was the best for number of leaves per plantlets.

Leaf length: Length of leaves produced per plantlet varied on MS medium supplemented with different cultivars and concentrations of BAP were used. The response of cultivars on leaf increment at different DAI was found significant. Among the concentrations of BAP, $5.0 \mathrm{mg} / \mathrm{l}$ showed the longest and $1.0 \mathrm{mg} / \mathrm{l}$ showed the shortest leaf in both the cultivars at different DAI. Amritasagar produced $2.29 \mathrm{~cm}$ leaf at $5.0 \mathrm{mg} / \mathrm{l} \mathrm{BAP}$ at 30 DAI while Sabri produced $1.86 \mathrm{~cm}$ leaf (Table 05). These results were in partial support of Rabbani et al. (1996) who obtained longest leaf with $5.0 \mathrm{mg} / \mathrm{l}$ each of BAP and Kinetin. BAP used on the culture media @ $0.5 \mathrm{mg} / \mathrm{l}$ provided the longest leaf (Khanam et al., 1996). 
Table 05. Combined effect of cultivars and concentrations of BAP on number of leaves and leaf length

\begin{tabular}{|c|c|c|c|c|c|c|c|}
\hline \multirow[t]{2}{*}{ Cultivars } & \multirow{2}{*}{$\begin{array}{c}\text { Conc. of } \\
\text { BAP } \\
(\mathrm{mg} / \mathrm{l})\end{array}$} & \multicolumn{3}{|c|}{$\begin{array}{l}\text { Number of leaves per plantlets at } \\
\text { different days after inoculation }\end{array}$} & \multicolumn{3}{|c|}{$\begin{array}{l}\text { Leaf length }(\mathrm{cm}) \text { at different days } \\
\text { after inoculation }\end{array}$} \\
\hline & & 10 days & 20 days & 30 days & 10 days & 20 days & 30 days \\
\hline \multirow{8}{*}{ 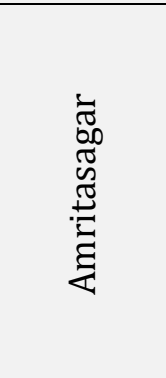 } & 0.0 & 0.00 & 0.00 & 0.00 & 0.00 & 0.00 & 0.00 \\
\hline & 1.0 & 0.00 & 0.67 & 1.17 & 0.00 & 0.04 & 0.72 \\
\hline & 2.0 & 0.50 & 1.17 & 2.33 & 0.03 & 0.55 & 1.48 \\
\hline & 3.0 & 1.00 & 2.17 & 3.50 & 0.07 & 1.05 & 1.85 \\
\hline & 4.0 & 1.00 & 2.33 & 3.50 & 0.07 & 1.11 & 1.91 \\
\hline & 5.0 & 1.50 & 2.50 & 4.11 & 0.11 & 1.21 & 2.29 \\
\hline & 6.0 & 0.67 & 1.00 & 2.17 & 0.05 & 0.60 & 1.72 \\
\hline & 7.0 & 0.00 & 0.50 & 1.50 & 0.00 & 0.12 & 0.78 \\
\hline \multirow{8}{*}{ 离 } & 0.0 & 0.00 & 0.00 & 0.00 & 0.00 & 0.00 & 0.00 \\
\hline & 1.0 & 0.00 & 0.00 & 0.50 & 0.00 & 0.00 & 0.53 \\
\hline & 2.0 & 0.00 & 0.50 & 2.00 & 0.00 & 0.14 & 0.93 \\
\hline & 3.0 & 0.00 & 1.00 & 2.00 & 0.00 & 0.41 & 1.29 \\
\hline & 4.0 & 0.00 & 1.19 & 2.17 & 0.00 & 0.56 & 1.48 \\
\hline & 5.0 & 0.00 & 1.67 & 2.67 & 0.00 & 0.72 & 1.86 \\
\hline & 6.0 & 0.00 & 1.17 & 1.50 & 0.00 & 0.19 & 1.46 \\
\hline & 7.0 & 0.00 & 1.15 & 1.00 & 0.00 & 0.13 & 0.71 \\
\hline
\end{tabular}

\section{Different concentration of IBA on root induction}

Number of roots per plantlet: In vitro root induction for Amritasagar and Sabri cultivar was shown in Plate 5and 6 at $3.0 \mathrm{mg} / \mathrm{l}$ IBA after 30 DAI. Maximum number of roots per plantlets was found from $3.0 \mathrm{mg} / \mathrm{l} \mathrm{IBA}$ in both cultivars (4.10 in Amritasagar and 3.63 in Sabri) at 30 DAI whereas no response was observed in control (Table 06). $3.0 \mathrm{mg} / \mathrm{l}$ IBA was the best treatment among all concentrations of BAP for this parameter (Habib, 1994; Rabbani et al., 1996; Raut and Lokhande, 1989). Amritasagar produced more number of roots than Sabri.

Root length: Longest root was found from $3.0 \mathrm{mg} / \mathrm{l}$ IBA $(3.60 \mathrm{~cm}$ in Amritasagar and $3.10 \mathrm{~cm}$ in Sabri at $30 \mathrm{DAI}$ ) and $1.0 \mathrm{mg} / \mathrm{l}$ produced the shortest root in both the cultivars at different DAI whereas no response was observed in control. $3.0 \mathrm{mg} / \mathrm{l}$ IBA was the best treatment among all the concentrations for this parameter (Bhaskar et al., 1993).

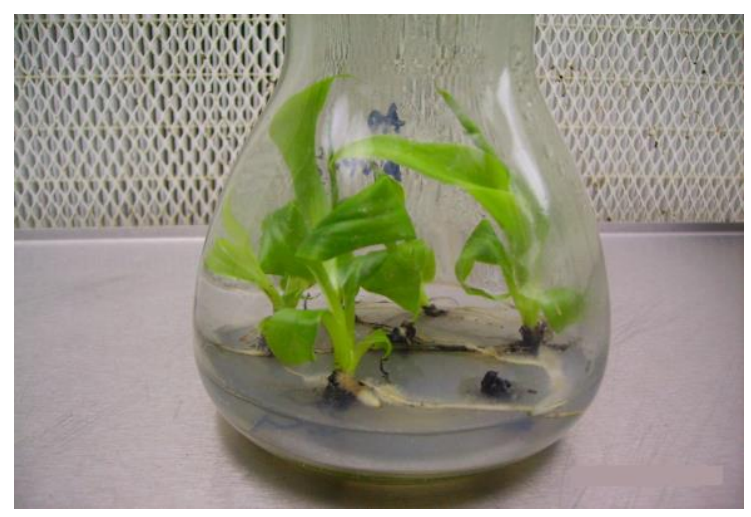

Plate 05. In vitro root induction of Amritasagar at $3.0 \mathrm{mg} / \mathrm{l}$ IBA after $30 \mathrm{DAI}$

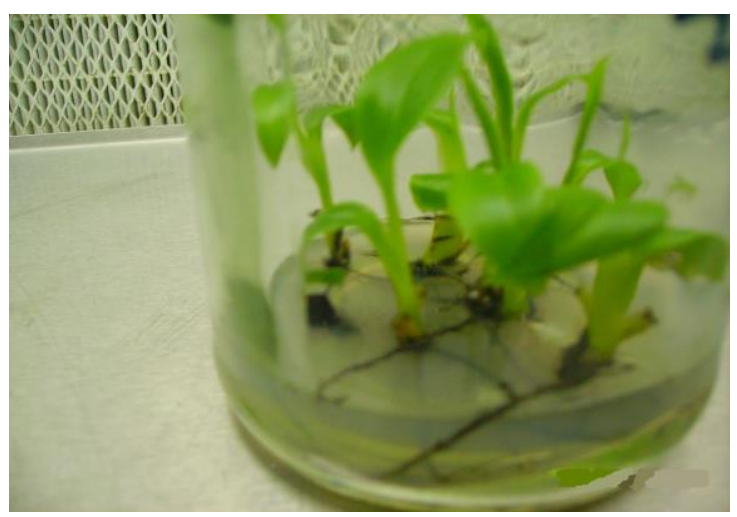

Plate 06. In vitro root induction of Sabri at $3.0 \mathrm{mg} / \mathrm{l}$ IBA after $30 \mathrm{DAI}$ 
Table 06. Combined effect of cultivars and concentrations of IBA on root number and root length

\begin{tabular}{|c|c|c|c|c|c|c|c|}
\hline \multirow[t]{2}{*}{ Cultivars } & \multirow{2}{*}{$\begin{array}{c}\text { Conc. of } \\
\text { IBA } \\
(\mathrm{mg} / \mathrm{l})\end{array}$} & \multicolumn{3}{|c|}{$\begin{array}{c}\text { Roots per plantlet at different days } \\
\text { after inoculation }\end{array}$} & \multicolumn{3}{|c|}{$\begin{array}{l}\text { Root length }(\mathrm{cm}) \text { at different days } \\
\text { after inoculation }\end{array}$} \\
\hline & & 10 days & 20 days & 30 days & 10 days & 20 days & 30 days \\
\hline \multirow{6}{*}{ 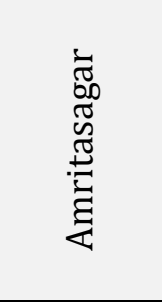 } & 0.0 & 0.0 & 0.0 & 0.00 & 0.00 & 0.00 & 0.00 \\
\hline & 1.0 & 0.42 & 1.0 & 1.27 & 0.10 & 0.57 & 1.14 \\
\hline & 2.0 & 1.60 & 2.92 & 3.21 & 0.45 & 1.20 & 2.30 \\
\hline & 3.0 & 1.67 & 3.83 & 4.10 & 0.98 & 2.20 & 3.60 \\
\hline & 4.0 & 1.74 & 2.60 & 3.72 & 0.90 & 1.55 & 2.72 \\
\hline & 5.0 & 0.83 & 2.08 & 3.01 & 0.85 & 1.60 & 2.00 \\
\hline \multirow{6}{*}{$\frac{\pi}{\pi}$} & 0.0 & 0.0 & 0.0 & 0.00 & 0.00 & 0.00 & 0.00 \\
\hline & 1.0 & 0.0 & 0.47 & 0.60 & 0.00 & 0.40 & 0.90 \\
\hline & 2.0 & 0.42 & 1.25 & 2.42 & 0.25 & 0.76 & 2.07 \\
\hline & 3.0 & 1.08 & 2.50 & 3.63 & 0.58 & 1.90 & 3.10 \\
\hline & 4.0 & 0.93 & 1.75 & 2.42 & 0.47 & 1.20 & 1.72 \\
\hline & 5.0 & 0.83 & 1.33 & 2.30 & 0.46 & 1.02 & 1.35 \\
\hline
\end{tabular}

\section{Ex vitro hardening of plantlets}

The plantlets with well-developed roots were removed from the culture vessels without damaging the roots. The culture media was washed away from the roots with running tap water. After that, the plantlets were treated with fungicide (1.5-2 g/l Ridomil) for 20 minutes to prevent unwanted fungal or bacterial growth in the roots. These plantlets were transferred to small polythene bag filled with soil, sand and well decomposed cow dung (1:1:1) and kept in the hardening room for 5-8 days. Then the polythene bags containing plantlets were transferred to net house, where proper care was taken for growth and development of banana plantlets. After 15-20 days, maximum plantlets showed vigorous growth while some were less vigorous. These plantlets were transferred to the field conditions after 30 days where they grew under conditions of normal environment. The survival rate of plantlets was more than $82 \%$ for both the cultivars. $80 \%$ survival of plantlets was found under ex vitro condition (Azad and Amin, 1999) and similarly by Cronaur and Krokorian (1984a and 1984b).

\section{Conclusion}

Application of $0.5 \mathrm{mg} / \mathrm{l} \mathrm{BAP}$ and $0.3 \mathrm{mg} / \mathrm{l} \mathrm{IBA}$ as growth supplements on MS culture media help to perform better for new plantlet regeneration capability through In vitro shoot-tip culture of Banana. BAP concentration $0.5 \mathrm{mg} / \mathrm{l}$ and IBA concentration of $0.3 \mathrm{mg} / \mathrm{l}$ was found best concentration for shoot proliferation and root elongation in both cultivars of banana. On the other hand, Application of more than $0.5 \mathrm{mg} / \mathrm{l}$ BAP and $0.3 \mathrm{mg} / \mathrm{l}$ IBA gradually decreases In vitro culture developments for all parameters as observed for shoot proliferation and root elongation. But for the commercial plantlet regeneration, Amritasagar was found better than Sabri cultivar with $0.5 \mathrm{mg} / \mathrm{l} \mathrm{BAP}$ and $0.3 \mathrm{mg} / \mathrm{l} \mathrm{IBA}$ for shoot regeneration and root formation respectively.

\section{References}

[1]. Ali, M. R., Akand, M. H., Hoque M. E., Homayra Huq, Mehraj, H. and Jamal Uddin, A. F. M. (2015). In vitro regeneration and rapid multiplication of tuberose. Int. J. Bus. Soc. Sci. Res. 3(1): 35-38.

[2]. Ali, M. R., Mehraj, H. and Jamal Uddin, A. F. M. (2014). Kinetin (KIN) and Indole-3- Acetic Acid (IAA) on In vitro shoot and root initiation of tuberose. Int. J. Sustain. Agril. Tech. 10(8): 1-4.

[3]. Azad, M. A. K. and Amin, M. N. (1999). In vitro propagation and conservation of banana (Musa spp). Abstracts, Third International Plant Tissue Culture Conference held during 8-10 March, 1999, Dhaka, Bangladesh. p. 12. 
[4]. Bhaskar, J., Arvindakchan, M., Valsalakumari, P. K. and Rajeevan, P. K. (1993). Micropropagation studies in banana. South Indian Hortic. 41(4): 186า-191.

[5]. Buah, J. N., Danso, E., Taah, K. J., Abole, E. A., Bediako, E. A., Asiedu, J. and Baidoo, R. (2010). The effects of different concentration cytokinins on the In vitro multiplication of plantain (Musa sp.). Biotechnology 9(3): 343-347.

[6]. Cronauer, S. S. and Krikorian, A. D. (1984a). Multiplication of Musa from excised stem tips. Annals Bot. 53(3): 321-328.

[7]. Cronauer, S. S. and Krikorian, A. D. (1984b). Rapid multiplication of banana and plantins by in vitro shoot tip culture. Hort. Sci. 19(2): 234-235.

[8]. Cronauer, S. S. and Krikorian. A. D. (1983). Somatic embryos from culture tissue of triploid plantain (Musa, ABB). Plant Cell Rep. 3(2): 289-291.

[9]. Domingues, E. T., Tulmann, N. A. and Mendes, B. M. J. (1995). Culture of shoot tips of Musa spp. cv. Maca: establishment, micropropagation and rooting in vitro. Scientia Agric. 52(2): 287-394.

[10]. Dore, R., Srinivasa, N. K. and Chacko, E. K. (1983). Tissue cultue propagation of banana. Scientia Hort. 18: 247-252.

[11]. Faisal, S. M., Haque, M. A. and Quasem, A. (1998). Field performance of in vitro plantlets aganinst normal suckers of banana (Musa sapientum) cv. Champa. Plant Tissue Cult. 8(2): 125-129.

[12]. Farahani, F., Aminpoor, H., Sheidai, M., Noormohammadi, Z. and Mazinani, M. H. (2008). An improved system for in vitro propagation of banana (Musa acuminate L.) cultivars. Asian J. Plant Sci. 7(1): 116-118.

[13]. Habib, A. (1994). Mass propagation of Mussa sapientum var. Sagar and performance of different genotype of Mussa cavendishii (Grand Naine) in Bangladesh. M.S. Thesis, Dept. of Botany, University of Dhaka. p. 53.

[14]. Jatoi, S. K., Sajid, G. M., Sappal, H., Baloch, M. S., Qureshi, A. and Anwar, R. (2001). Differential in vitro response of tomato hybrids against a multitude of hormonal regimes. Online J. Biol. Sci. 1: 1141-1143.

[15]. Khanam, D., Haque, M. A., Khan, M. A. and Quasem, A. (1996). In vitro propagation of banana (Musa spp). Plant Tiss. Cult. 6(2): 89-94.

[16]. Madhulatha, P., Anbalagan, M., Jayachandaran, S. and Sakthivel, N. (2004). Influence of liquid pulse treatment with growth regulators on In vitro propagation of banana (Musa sp. AAA). Plant Cell Tissue Organ Cult. 76: 189-192.

[17]. Momena, K., Adeeba, R., Mehraj, H., Jamal Uddin, A. F. M., Saiful Islam and Rahman, L. (2014). In vitro microtuberization of potato (Solanum tuberosum L.) cultivar through sucrose and growth regulators. Journal of Bioscience and Agriculture Research 2(2): 76-82.

[18]. Murashige, T. and Skoog, F. (1962). A revised medium for rapid growth and bioassays with tobacco tissue cultures. Physiologia Plantarum. 15: 473-497

[19]. Pradeep, K. P., Zachariah, G., Estelitta, S. and Suma. A. (1992). Field performance of banana tissue culture plants of variety Nendran (Musa AAB). South Indian Hort. 40(1): 1-4.

[20]. Rabbani, M. G., Ali, M. H. and Mondal, M. F. (1996). Effect of BAP and IBA on micropropagation of some banana cultivers. Bangladesh Hort. 25(1 \& 2): 47-52.

[21]. Rahman, M. Z., Sharoar, M. G., Matin, M. N., Rahman, M. H., Rahman, M. M. and Islam, M. R. (2006). High frequency plant regeneration of a dessert banana cv. mehersagar for commercial exploitation. Biotechnology 5(3): 296-300.

[22]. Ranjan, R., Bhagat, B. K., Hiaider, Z. A. and Jain, B. P. 2001. Rapid in vitro propagation of different banana species. Orissa J. Hort. 29(1): 34-36.

[23]. Raut, R. S. and Lokhande, V. E. (1989). Propagation of plantain through meristem culture. Ann. Plant Physiol. 3(2): 256-260.

[24]. Resmi, L. and Nair, A. S. (2007). Plantlet production from the male inflorescence tips of Musa acuminata cultivars from South India. Plant Cell Tissue Organ Cult. 88: 333-338.

[25]. Rehana, S. 1999. Effect of BAP and IBA on in vitro regeneration, shoot multiplication and rooting of four cultivars of banana. M.S. Thesis, Department of Genetics and Plant Breeding, BAU, Mymesnignh.

[26]. Vessey, J. C. and Revera, J. A. (1981). Meristem culture of banana's. Turriaba. 31: 162-163. 